\title{
8.3. СУЩНОСТЬ И СТРУКТУРА ЭКОНОМИЧЕСКОЙ БЕЗОПАСНОСТИ РЕГИОНА
}

Киселева И. А., д.э.н., профессор, профессор кафедры математических методов в экономике, Российский экономический университет им. Г.В. Плеханова, г. Москва;

Искаджян С. О., к.э.н., заведующий кафедрой экономических наук Ереванского фрилиала Российского экономического университета им. Г.В. Плеханова, г. Ереван

Статья посвящена вопросам изучения сущности и структуры экономической безопасности регионов как ключевых составляющих экономической безопасности государства. В современном мире глобализации для государств становятся крайнее актуальными вопросы экономической независимости, стабильности и самодостаточности регионов. В данной работе проанализированы составляющие экономической безопасности региона. Сделаны выводы о необходимости классификации экономических угроз региона, определения их роли и значимости в структуре экономической безопасности региона.

\section{Литература}

1. Балабанов И.Т. Риск-менеджмент [Текст] / И.Т. Балабанов. - М. : Финансы и статистика, 1996. - 254 с

2. Валько Д.В. Экономическая безопасность [Текст] : учеб. пособие для вузов / Д.В. Валько. - М. : Юрайт, 2019. - 150 с.

3. Гончаренко Л.П. т др. Экономическая безопасность [Текст] : учеб. для вузов / Л.П. Гончаренко [и др.] ; под общ. ред. Л.П. Гончаренко. - 2-е изд., перераб. и доп. - М. : Юрайт, 2019. - 340 с.

4. Киселева И.А. Концепция экономической безопасности в туристской сфере [Текст] / И.А. Киселева, С.О. Искаджян // Economics. - 2018. - №1. - C. 20-24.

5. Кузнецова Е.И. Экономическая безопасность и конкурентоспособность. Формирование экономической стратегии государства [Текст] : монография / Е.И. Кузнецова. - М. : ЮНИТИ, 2017. - 239 с.

6. Кутукова Е.С. Экономическая безопасность в призме современных экономических процессов [Текст] / Е.С. Кутукова. М. : Русайнс, 2017. - 352 с

7. Попов М.В. и др. Экономическая безопасность [Текст] : учеб. пособие / М.В. Попов, М.А. Каткова, Н.В. Манохина, Л. Мамаева. - М. : ИНФРА-М, 2018. - 576 с.

8. Уразгалиев В.Ш. Экономическая безопасность [Текст] : учеб. и практикум для вузов / В.Ш. Уразгалиев. - 2-е изд., перераб. и доп. - М. : Юрайт, 2019. - 675 с.

9. Шпиловская Е.В. Методология оценки уровня жизни населения в аспекте концепции качества населения [Текст] / Е.В. Шипиловская // Гуманит. и соц.-экон. науки. - 2015. - №6. - С. 127-132.

10. Яковлев В.М. Риски и экономическая безопасность муниципальных образований [Текст] / В.М. Яковлев. - М. : Русайнс, 2017. - 736 с.

11. Iskajyan S.O. et al. Features of risk assessment in the digital economy: MISMA [Text] / S.O. Iskajyan, I.A. Kiseleva, N.E. Simonovich, N.P. Tikhomirov, T.M. Tikhomirova. - Yerevan, 2018. - 117 p.

\section{Ключевые слова}

Экономическая безопасность; угрозы; регионы; рынок; развитие регионов; экономическая стабильность; независимость экономики; управление рисками; развития государство; способность к самодостаточности; защита интересов.

\section{Киселева Ирина Анатольевна}

\author{
Искаджян Симон Оганнесович
}

\section{РЕЦЕНЗИЯ}

Актуальность работы. В статье рассматриваются важные вопросы экономической безопасности регионов как составляющей социальноэкономической системы государства и различные виды рисков. Основополагающим аспектом в деятельности активного участника финансового рынка является принятие решений в условиях риска и неопределенности. Для создания стратегии экономической безопасности исследуются факторы, которые могут повлиять на положение региона в рыночных условиях. Важнейшим аспектом проблемы экономической безопасности региона является отбор критериев, позволяющих оценить ее уровень, а также расчет пороговых значений для каждого критерия.

Научная новизна и практическая значимость. В условиях усложнения экономических связей между отдельными субъектами, усиления процессов глобализации и интеграции наблюдается существенное увеличение числа экономических угроз, что предопределяет необходимость создания эффективной концепции экономической безопасности на всех уровнях хозяйствования субъектов.

Авторы отмечают, что экономическая безопасность региона зависит от правильной идентификации рисков, их анализа и применения методов по устранению рисков. Следует согласиться с мнением авторов, что для того, чтобы обеспечить экономическую безопасность региона, его стабильное функционирование и

устойчивую позицию на рынке, необходимо управление рисками с целью их минимизации, а также проведение обязательных мер по снижению последствий и потерь от рисков. 
В статье сделан вывод, что разработка и реализация комплексной системы обеспечения экономической безопасности регионов позволит прогнозировать угрозы экономической безопасности, а также качественно воздействовать на общее финансовое состояние конкретного региона.

По стилю статьи можно определить, что работа изложена научным понятным языком и имеет четко сформированную структуру, соответствующую цели исследования. Стиль, логика и доступность изложения материала статьи соответствует научному характеру материала, выводы, полученные в статье, достоверны и обоснованы.

Заключение: статья представляет собой самостоятельную, законченную научно-исследовательскую работу, выполненную на актуальную тему, на высоком теоретическом уровне, она отвечает требованиям, предъявляемым к научным публикациям, и может быть рекомендована к опубликованию.

Кузнецов В.И., д.э.н., профессор, профессор кафедры отраслевой и бизнес-статистики Российского экономического университета им. Г.В. Плеханова, г.Москва.

DOI 10.38097/AFA.2020.44.74.027 